\title{
Effect of essential oils on vase life of cut flowers of Solidago Canadensis L. (Golden rod)
}

\author{
Amani Ismail Adam \\ Antoniadis Research Branch, Ornamental Plants Research and Landscape Gardening Res. Dept., Hort. Res. inst., \\ ARC, Alexandria, Egypt. \\ "Corresponding author email: amaniadm@ hotmail.com
}

Received on: 5-5-2021

Accepted on: 25-5-2021

\begin{abstract}
The present study was done at Antoniades Research Branch, Ornamental Plants Research and Landscape Gardening Res. Dept., Hort. Res. inst., ARC, Alexandria, Egypt, during the two successive seasons of 2019 and 2020. The aim of this work was to evaluate the ability to use Nigella sativa, Rosmarinus officinalis and Citrus lemon essential oils (EOs) at $0.0,50,100,200 \mathrm{mg} / \mathrm{l}$ as holding solution on reducing bacterial decay and prolonging the vase life of solidago cut spike. The highest significant increase in vase life was obtained after application of Nigella Eo at $200 \mathrm{mg} / \mathrm{l}$ which was 15.78days in the first and 16.85 in the second season respectively as the compared to rosemary, lemon oils and control treatments. While the vase life of control treatment was 6.98 and7.00 days in both seasons respectively. Also, this treatment recorded the highest significant increase in final water uptake, shoot fresh weight/shoot dry weight ratio and chlorophyll a \& b content. Moreover, this treatment caused decreased in the loss of flower fresh weight and reduced the number of bacterial colonies in vase solution.
\end{abstract}

KEYWORDS: Essential oils, solidago (Solidago canadensis, L), cut spike, Nigella Eo.

\section{INTRODUCTION}

Golden rod (Solidago canadensis L., fam: Asteraceae) is a weedy plant that is commonly found in its north American region, considered as an ornamental plant (Melville, 1982). It has been recognized for years as a landscape plant. solidago is an excellent cut flower commonly used for vases and bowls of indoor decoration.solidagocut flowers has been dramatically increased over the past three years, it is a new crop among the top 25 most popular cut flowers around the world. This promising crop could be adopted to be produced under natural Egyptian conditions, with minimum environmental control, for export to the European markets during the off seasons in winter and early spring months (Flower council of Holland, 1999).

Cut flowers have a limited shelf life and are traditionally planted near market centers to make the maximum use of flowers possible for the consumers. The distribution problem is that the flowers should now be transported throughout the world wide and the life of the flowers should be termed to provide the cut flower in good quality to the consumers (Zeltzeret al., 2001). The main reason that affect for the vase life of cut flowers is the microbial contamination (Kazemiet al., 2011). The life of the cut flowers in vessels after harvesting is often affected with microbes, physiological occlusion or stem occlusion. It causes the water not to be absorbed or extracellular enzymes secrete that can damage the vascular tube cell walls (Damunupolaet al., 2010). The use of natural substances which have no side effects on human health and the environment and which are relatively cheap, because most chemicals are toxic and they cause environmental pollution, is very important (Okigbo 2005). Some herbal extracts and essential oil have antimicrobial properties and are used for their impact on prolonging life after harvesting horticultural products. Essential oils (EOs), which have various anti-oxidant, antibacterial or antifungal properties, are organic or natural products from aromatic and medicinal plants (Teissedre and Waterhouse, 2000; Bayatet al., 2013), these can be used these oils as the preservative solutions to control bacterial and fungal pathogens (Hegazi and EL Kot., 2009; Solgiet al., 2009; El-Hanafy, 2007).

Essential oils of Nigella sativa (black caraway, also known as black cumin) are an annual flowering plant in the Ranunculaceae family. Thymoquinone is the main constituent of the essential oil of $\mathrm{N}$. sativa seeds, in addition the thymoquinone and its degradation product the thymohydroquinone have been reported to have antibacterial activity (Tembhurneet al., 2014: Nickavaret al., 2003). On carnation cut flowers, a solution containing $100 \mathrm{mg} / \mathrm{l}$ black cumin essential oil was found more effective than the control, particularly in terms of vase life and flower fresh 
weight losses. (Bazaz and Tehranifar (2011),Fariman and Tehranifar, (2011)Hashemabadi et al. (2012) and Shanan, 2012).

Rosmarinus officinalis, L. Lamiaceae family is a rich source of phenolic compounds. In addition to the volatile constituents, EO of rosemary also contain several antioxidant components, pinene and camphor which belong mainly to the classes of phenolic acids, flavonoids, and diterpenoids(Steinegger and Hancel, 1998). The use of a treatment containing $25 \%$ rosemary extract and $6 \%$ sucrose in the Dianthus preservative solution expanded the vase life of flowers to 24 days (Basiriet al., 2011).

Lemon (Citrus lemon) (Fam Rutaceae) plant is valuable source of essential oil, which is used in foods and medicines. Lemon oil contains linalool, it is an alcoholic monoterpene and have shown strong bacteriostatic properties (Sue Clarke 2008).

The addition of essential oils to preservative solutions could reduce the microbial density and increase the vase life of flowering spikes (Van Meetern et al., 2001; Hegazi and El-Kot, 2009).Essential oils lead to an increase in the permeability of bacteria cell due to the in capability of cell membrane to separate the constituents can lead to destabilization of the phospholipid layer of cytoplasmicthis damage causes cell inactivation and/or death (Borges et al 2013). The mechanism of action of EOs are completely dependent on their chemical ingredientsand it was demonstrated that alcohols, aldehydes ,terpenes, phenols, ketones, ethers and hydrocarbonsin natural essential oil were largely responsible forinhibition of the bacteria.The antimicrobial action ofmonoterpenes suggest that they can easily diffuseinto or penetrate through the damaged cell membrane sructures of microorganisms. Therefore, essential oils rich in terpenes have been shown to good possess antibacterial (Mohammad and Hassan 2017). In general, EOs act to inhibit the growth ofbacterial cells and also inhibit the production of toxic bacterial (Burt, 2004).

The study was carried out to investigate the effect of using some natural essential oils rosemary, lemon, and nigella of various concentrations as preservative solutions on the vase life of golden rod (Solidagoc anadensis) cut flowers, as well as to improve their quality and extend their shelf-life period.

\section{MATERIALS AND PROCESSES}

This experiment was carried out in the Laboratory of Antoniades Research Branch, Ornamental Plants Research and Landscape Gardening Res. Dept., Hort. Res. inst., ARC,
Alexandria, Egypt, over two consecutive seasons in 2019 and 2020.

\subsection{Source of the cut flowers}

Solidago (Solidago canadensis, L) cut spikes were brought from a well-known commercial nursery in Alexandria.

\subsection{Cut flowers preparations}

Solidago cut spike at the normal commercial harvest stage at $10 \%$ of florets are opened according to ( Brahmankaret et al, 2005). The uniform flowers were cut in the early morning, wrapped using polyethylene, and then quickly moved to the laboratory under dry condition. The stems were recut under water to $50 \mathrm{~cm}$ in length, with the 45degree angle (Khimani et al., 2005) and lower leaves were removed at the end of the third part of stems. The experiment was started on the first of November 2019 and 2020 in the both seasons, respectively.

\subsection{Essemtial oils (EOs) used in the experiment}

The EOs used in this experiment was obtained from the National Research Centre(NRC) Dokki, Egypt.

\subsection{Post-harvest treatments}

\section{The following treatments were applied}

Pulsing treatments: The flower spikes were placed in different solutions containing essential oils of rosemary, lemon, nigella ( dissolve the oils in the preservative solution, Tween- 80 " $0.1 \% \mathrm{v} / \mathrm{v} "+10 \%$ ethyl alcohol were used) at concentration 0.0, 50, 100 and $200 \mathrm{mg} / \mathrm{l}$ for 24 hours. After that, the spikes were transferred to vases containing $500 \mathrm{~cm}^{3}$ tap water (three spikes per vase).

Lab conditions: The spikes were hold at the average temperature of $\left(17\right.$ to $\left.22{ }^{\circ} \mathrm{C}\right)$, under a $24-\mathrm{h}$ photoperiod with 500-550 Lux from white fluorescent light and the relative humidity was from $65 \%$ to $69 \%$ in the two seasons.

\subsection{Statistical analysis}

A randomized complete block design (RCBD)was used for the experimental layout, comprising ten treatments, each with three replicates. each contains three flower spikes were at a 5\% probability level, the L.S.D test was used to compared between the means of the treatment. Snedecor and Cochran's (1989) method of statistical analysis was used to analyses the data. 


\subsection{Data were recorded as the following}

\subsubsection{The postharvest characters}

\subsubsection{Vase life (days)}

It was calculated as the number of days between the beginning of the treatments and the fading stage of cut flowers. The fading stage was set to 75 percent wilting of the total number of inflorescence spikes.

\subsubsection{Loss of flower fresh weight percentage (LFFW)}

It was determined using the flowing formula during the fading stage.

LFFW $(\%)=\frac{\text { Initial fresh weight }- \text { Final fresh weight }}{\text { Initial fresh weight }} \times 100$

\subsubsection{Final water uptake (g):}

It was calculated at the end of the experiment as the following formula:

Water uptake $(g)=$ The amount of solution at the beginning of the experiment - the amount of the solution remaining at the end of the experiment.

\subsubsection{Flower fresh weight / flower dry weight ratio (FW/DW):}

To determine the flower dry weight, the flowers were oven-dried at $75^{\circ} \mathrm{C}$ for 48 hours (FDW.) The fresh weight (g) was then divided by the dry weight $(\mathrm{g})$ as shown below:

\section{FW/DW Ratio $=\frac{\text { Fresh weight per flower }(g)}{\text { Dry weight per flower }(g)}$}

\subsubsection{Relative fresh weight (RFW):}

Fresh weight of the flowers was determined just before the immersion of the flowers into the solutions and collected every two days until the vase life of the flowers was terminated. The fresh weight of each flower was expressed relative to the initial weight to represent the water status of the flower as follow:

\section{Relative fresh weight $($ RFW $)=\frac{W t}{W 0} \times 100$}

Where $W t$ is the weight of spike (g) at 2, 4, 6 days and $W_{0}$ is the initial fresh weight of the same spike (g).

\subsubsection{Vase solution uptake rate (VSU):}

calculated the VSU rate using the formula below:

$$
\text { VSU rate }=\frac{(S t-1)-S t}{\text { IFW of stem }} \times 100
$$

Where (St) is the weight of the vase solution (g) on 2,4,6 days, (St-1) is the grams of the vase solution on the entire past determination day while, and (IFW) is the initial fresh weight (g).

\subsubsection{Chemical analysis:}

Chlorophyll A and B content (mg/ g fresh weight) was determined in leaves according to Moran, (1982) in the upper part of flowering stems at the end of vase life of control plantand carotenoids (mg / $\mathrm{g}$ fresh weight) according to Wellburn (1994) and reducing sugars content (mg/g dry weight) was determined at the end of the experiment in the flower spike according to Miller (1959).

\subsubsection{Averages of bacterial counts (C.F.U /ml):}

Bacteria were counted according to their number of colonies confirmed by the Laboratory of Bacterial Plant Diseases and Molecular Bacteriology, Faculty of Agricultural, El-ShatbyAlexandria University. Serial dilutions were performed on vase solutions $(0.1 \mathrm{~mL})$ spread on general medium (nutrient agar) and incubated for 24 hours at $29{ }^{\circ} \mathrm{C}$. Number of colonies per petri dish was counted accurately. All bacterial counts were repeated three times (Balestraet al., 2005).

\section{RESULTS}

\subsection{Vase life (days)}

The application of essential oils (EOs) nigella, rosemary, lemon greatly improved the vaselife of solidago (Solidago canadensis, L) cut spikes. By varying the amounts of essential EOs in the preservation solution, the flowers of solidago were enlarged.

The vase life of solidago spikes have been extended at all concentrations used in (Table 1) .In both seasons, obtained data showed that nigella Eos $(200 \mathrm{mg} / \mathrm{l})$ had the largest significant impact on the vase-life extension (15.78 and $16.85 \mathrm{~d})$ as compared to the untreated plants $(6.98$ and $7.00 \mathrm{~d})$, also, there was non-significant differences between rosemary EO concentration of $200 \mathrm{mg} / \mathrm{l}(13.89$ and $13.87 \mathrm{~d})$ and nigella concentrations of $50 \mathrm{mg} / \mathrm{l}(13.48$ and $13.07 \mathrm{~d}$ ).At all concentration used, applying the different essential oils prolonged the vase life compared with the control. The findings revealed that the lemon EOs treatments had the shortest vase life (9.56 and 9.89 d) As compared to rosemary and lemon oil respectively, in both seasons.

\subsection{Loss of flower fresh weight percentage (LFFW\%):}

Results in Table (1) cleared that the lowest significant decreased in LFFW ratio was obtained after Nigella Eo at $200 \mathrm{mg} / \mathrm{l},(18.01$ and 19.40\%) in both seasons, respectively. On the other hand, the highest increase in LFFW was obtained after 
Table 1. Means of vase life (days), loss of flower fresh weight (LFFW) (\%), final water uptake (g/plant) and flower fresh weight/flower dry weight ratio (FWR) of Solidagocanadensisas affected by different concentrations of some essential oils $\left(\mathrm{Eo}_{\mathrm{s}}\right)$ during 2019 and 2020 seasons.

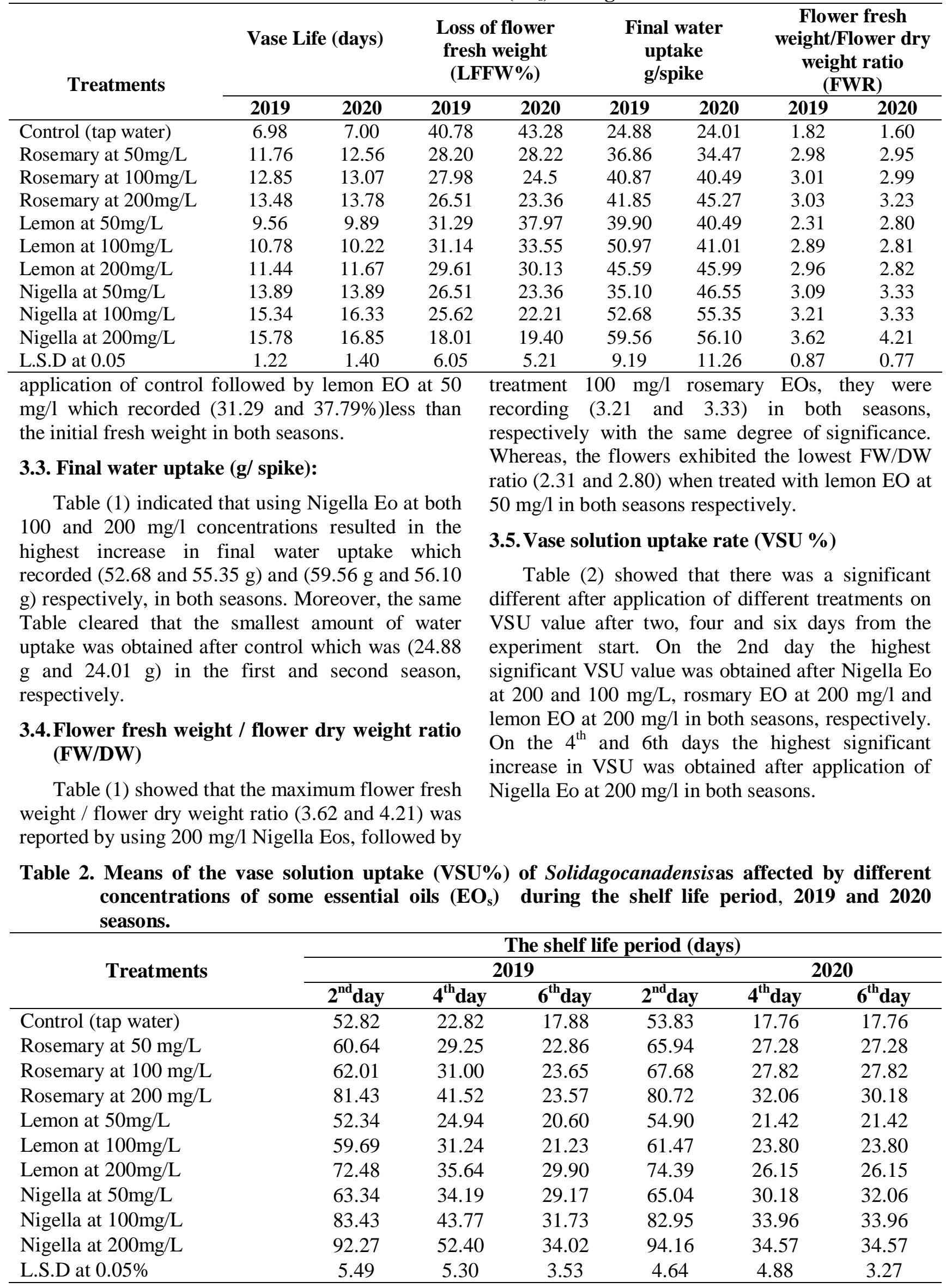


On contrary, the lowest significant VSU value was obtained after application of control after two, four and six days from the experiment start in both seasons.

\subsection{Relative fresh weight (RFW) \%}

Data in Table (3) cleared that there was a significant difference after application of different treatments on RFW value after two, four and six days from the experiment start. The Table cleared that application of Nigella Eo at $200 \mathrm{mg} / \mathrm{l}$ and rosemary EO at $200 \mathrm{mg} / \mathrm{l}$ resulted in the highest RFW value after two, four and six days from the experiment start in the first and second season with the same level of significance. On the other hand, application of tap water (control) recorded the smallest RFW after two, four and six days from the experiment start in both seasons.

Table 3. Means of the relative fresh weight (RFW \%) of Solidago canadensisas affected by different concentrations of some essential oils $\left(\mathrm{EO}_{\mathrm{s}}\right)$ during shelf life period in 2019 and 2020 seasons.

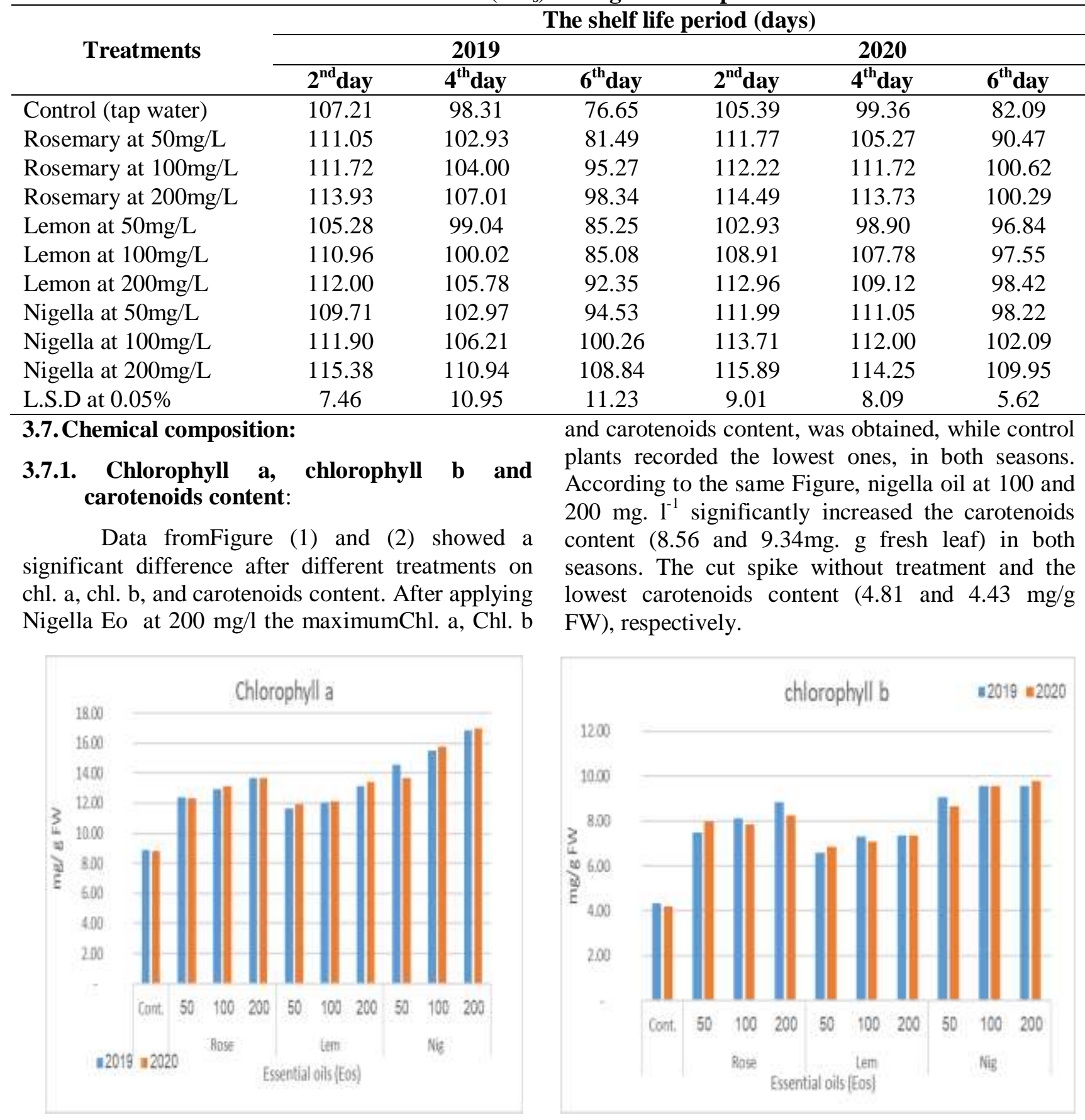

Fig 1. Effect of some essential oils at different concentrations on chlorophyll a and $b$ in the seasons of 2019 and 2020. 


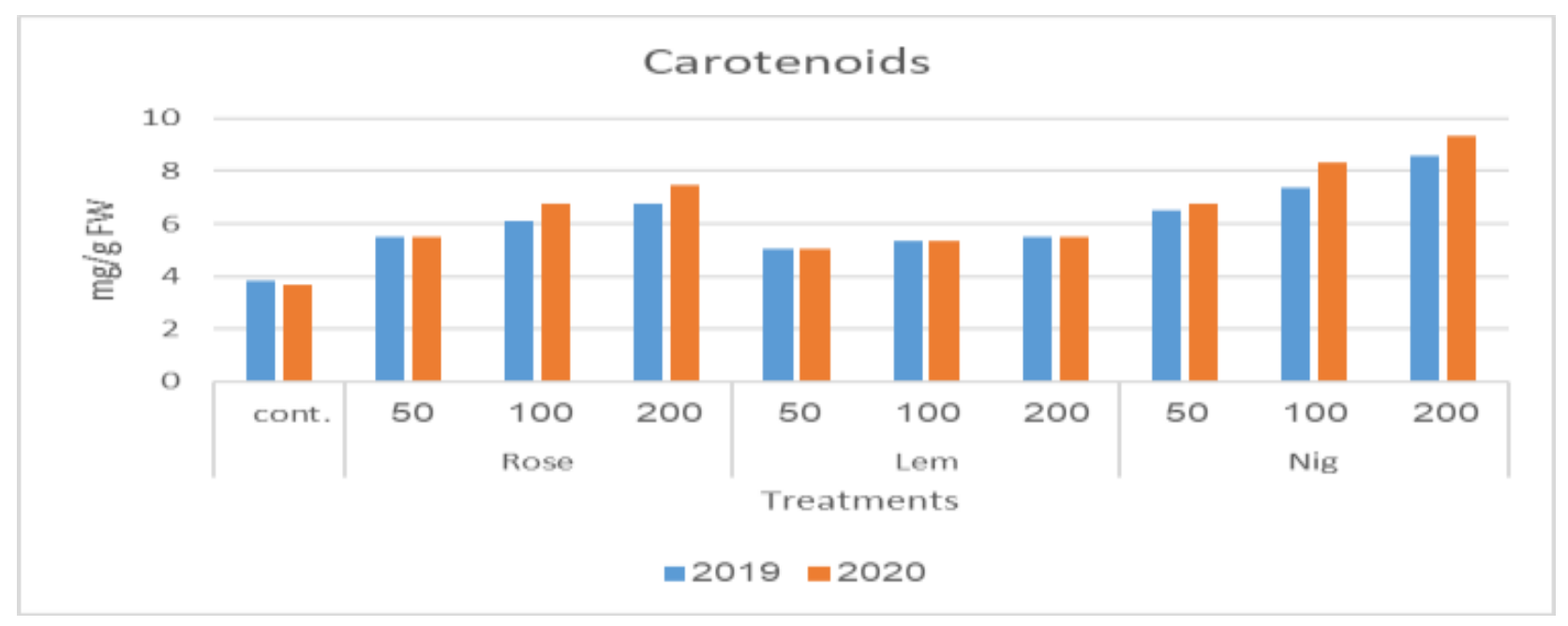

Fig 2. The effect of different essential oil (EO) levels on carotenoids mg/g FW in the seasons of 2019 and 2020.

\subsubsection{Reducing sugars content.}

Data in figure (3) revealed that there was a large variation in reducing sugar content by using various treatments as the highest reducing sugar content $(13.87$ and $13.19 \mathrm{mg} / \mathrm{g}$ dry weight) was obtained by using nigella Eo at $200 \mathrm{mg} / \mathrm{l}$ where's, using lemon EO $50 \mathrm{mg} / \mathrm{l}(9.43$ then $9.34 \mathrm{mg} / \mathrm{g}$ dry weight) resulted in the lowest reducing sugar content.

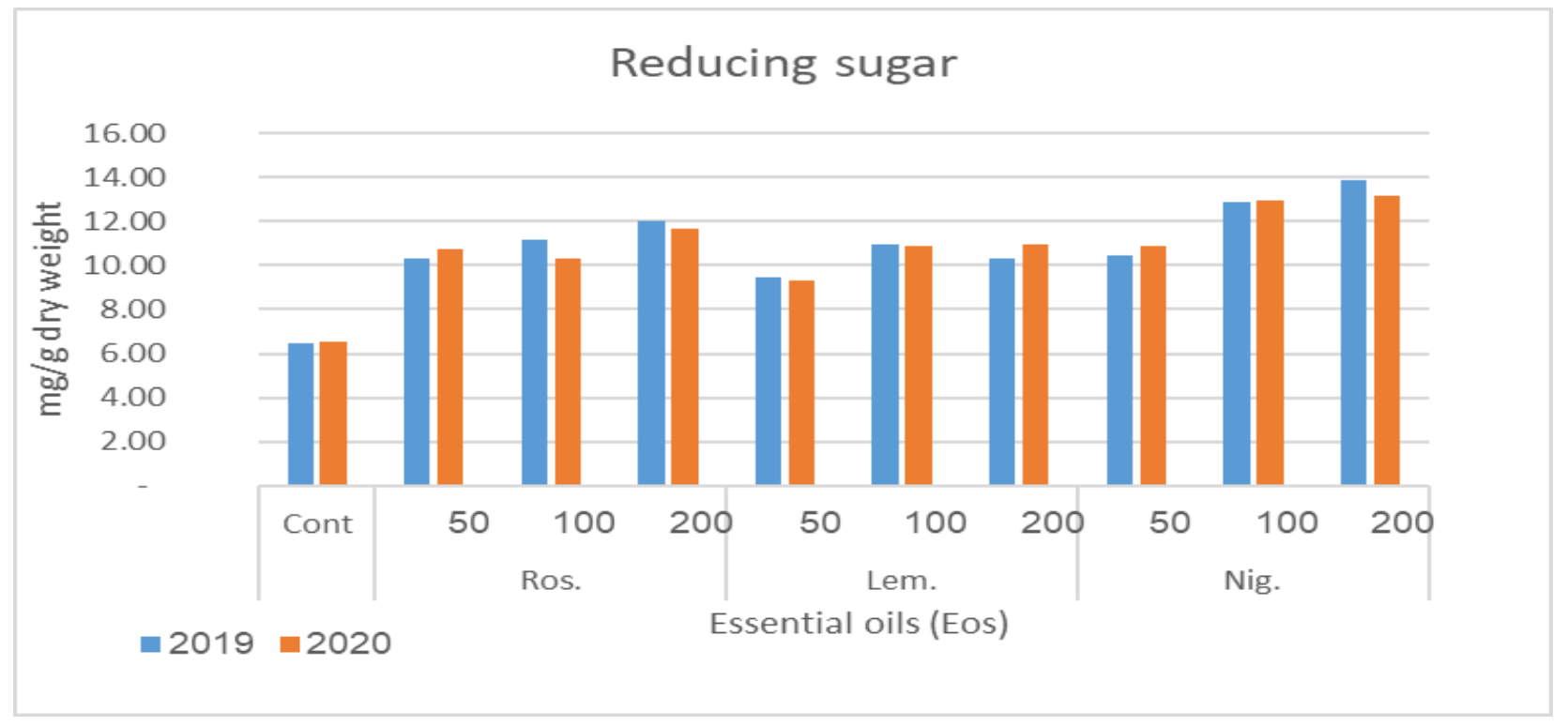

Fig 3. Effect of different levels of Essential oils (Eos) on reducing sugar (mg/g dw) in the seasons of 2019 and 2020.

\subsubsection{Number of bacterial colonies}

Data in Figure (4) showed that there was a significant difference in the number of bacterial colonies after application of different treatments. Control treatment recorded the highest number of bacterial colonies. All treatments caused significant decrease in the number and the highest significant reduction in bacterial colonies number was obtained by application of nigella oil at $200 \mathrm{mg} / \mathrm{lwhich}$ recorded (7.52X 105) $\mathrm{CFU} / \mathrm{ml}$ in the first season and treatments nigella at $100 \mathrm{mg} / \mathrm{l}(6.53 \mathrm{X} 105 \mathrm{CFU} / \mathrm{ml})$ and rosemary at $200 \mathrm{mg} / \mathrm{l}(11.11 \mathrm{X} 105 \mathrm{CFU} / \mathrm{ml})$ in the second season. After having the lowest significant number of bacterial colonies (nigella at 100 and $200 \mathrm{mg} / \mathrm{l}$ ), these treatments also had the lowest significant decrease in vase life (Table 1). Furthermore, in both seasons, the treatment nigella at $200 \mathrm{mg} / \mathrm{l}$ resulted in the most important statistical increase in vase life (15.78 and 16.85 days). This technique greatly decreased the number of bacterial colonies (7.52 X $105 \mathrm{CFU} / \mathrm{ml})$ and (6.53X 105 $\mathrm{CFU} / \mathrm{ml}$ ) in $1 \mathrm{st}$ and 2 nd seasons, respectively (Figure 4). 


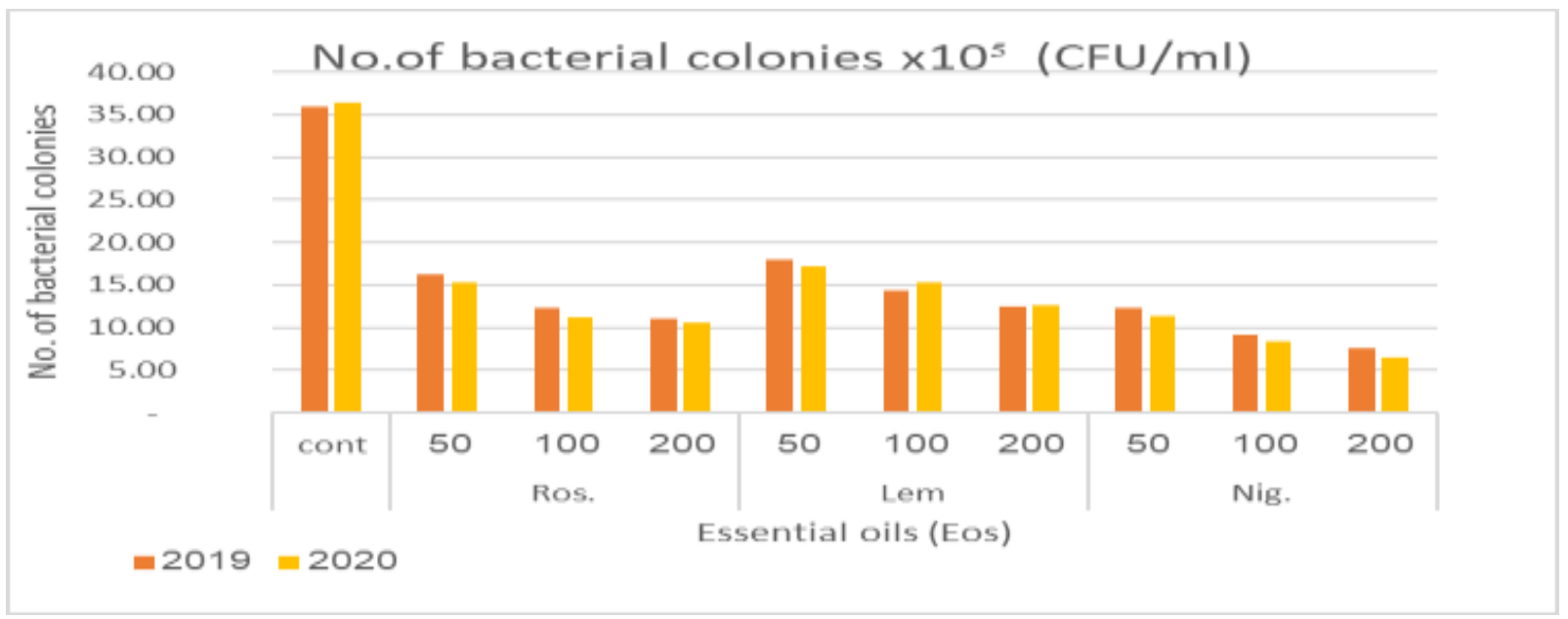

Fig 4. Effect of different concentrations of essential oils (EOs) on number of bacterial colonies (X 105 CFU/ml) in the seasons of 2019 and 2020.

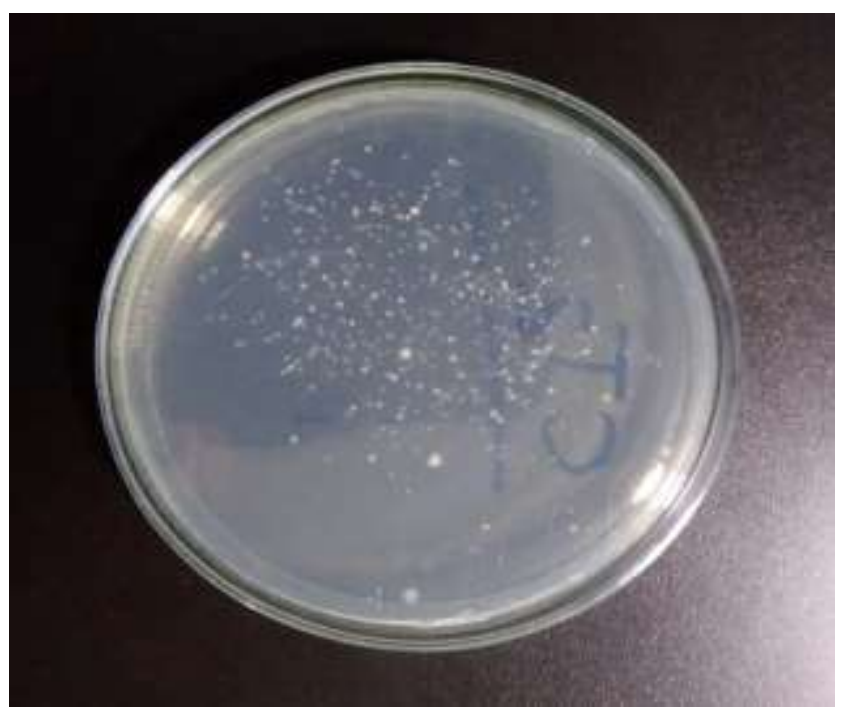

Control

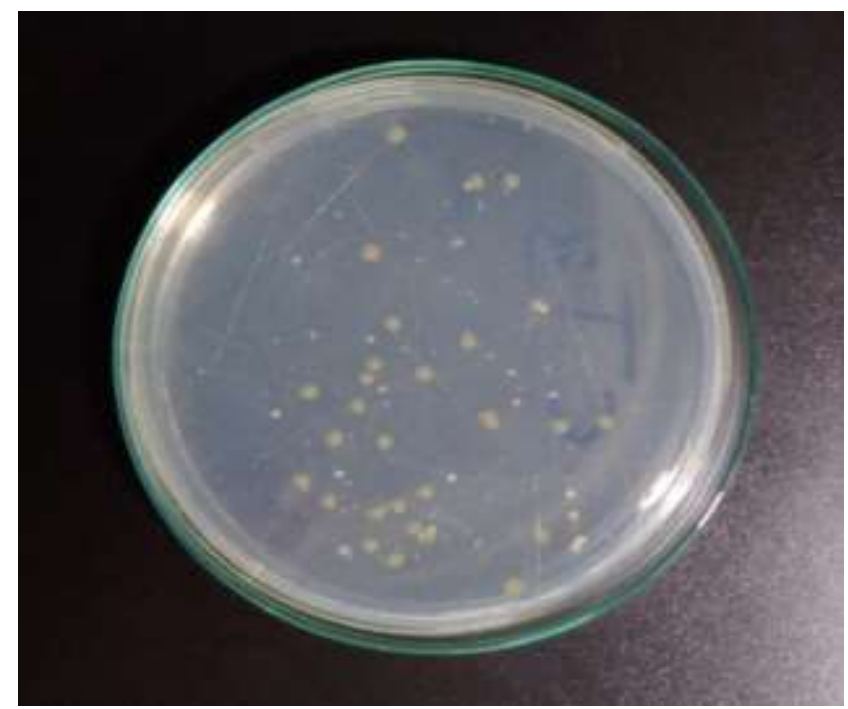

Nigella (EO) at $200 \mathrm{mg} / \mathrm{l}$

Fig 5. Pattern of bacterial abundance in vase solution on NA (nutrient agar) media treated with Nigella (EO) at $200 \mathrm{mg} / \mathrm{l}$ as compared to the control (Tap water).

\section{DISCUSSION}

The preliminary research for this experiment focused on the antibacterial and antifungal agents of three different purified natural essential oils on solidago (Solidago canadensis, L) cut spikes. The oils are obtained from rosemary, nigella, and lemon oil. Since reviewing results for all the values gathered with solutions containing oils, the authors opted to use one of this nigella oil, followed by rosemary and lemon oil.

The results cleared that the application of Nigella Eo at $200 \mathrm{mg} / \mathrm{l}$ resulted in the highest significant vase life (16.85 days) and decrement of the number of bacterial colonies of solidago
(Solidago canadensis, L) cut spikes over the two seasons. The current findings are consistent with (Hegazi and Gan2009) on Gladiolus and Lisianthus (Eustoma grandiflorum) (Bayatet al. 2013) cut flowers, in general, all essential oil preservative solutions can be concluded to considerably prolong the vase life compared with the distilled water (control), (Hossein et al., 2014).

These results can be construed to the essential oils lead to an increase in the permeability of bacteria cell due to the incapability of cell membrane to separate the constituents can lead to destabilization of the phospholipid layer of cytoplasmic and on cellular components of microorganisms, including essential enzymes in cell 
membranes and protoplasm this damage causes cell inactivation and death (Borges et al. 2013).

On the other hand, the highest significant decrease in the number of bacterial colonies was observed after the treatment of Nigella Eo at 200 $\mathrm{mg} / \mathrm{l}$. The reduction growth of the microorganisms caused decrement in stem blockage and increase final water uptake, decrement of LFFW, and increment of FW/DW Ratio, which resulted in an increment of flower longevity on solidago cut spike.

According to several studies, one of the most significant causes of decay in cut flowers is a reduction in water uptake due to occlusions, mostly at the basal stem end, which is most likely caused by microbe growth and vascular blockage, as well as an increase in water loss due to leaf transpiration $(\mathrm{He}$ et al., 2006 and Alimordiet al., 2013). Furthermore, the higher the measured leaf relative water content, the better the treatment's ability to retain water. Abbaszadehet al., 2008 and Hoogerwerf and Van Doorn, 1992).

When flowers are cut from the plant, water loss continues. The perfect flower preservative allows water absorption in flower tissues, or water absorption from the preservative solution maintains a better water balance and flower, enhancing vaselife. Our study cleared that recorded a high value of RFW and VSU along the first six days from the experiment start after application of Nigella Eo at $200 \mathrm{mg} / \mathrm{l}$ which may illustrate the freshness and longevity of stems after this treatment which probably helps in increasing water uptake, improved water balance which in turn helps in increasing fresh weight. (Irfan et al.,2018).

According to the findings of this study, plant essences, which are naturally degradable, safe, and environmentally friendly compounds, are suitable replacements for chemicals in the longevity increase after harvest of Gerbera (Hossein 2014).

According to the current findings, on day 7 of the study, measurements placed in untreated control were also under severe pressure and were unable to absorb and retain water adequately. In comparison, EO treatments were carried out under normal circumstances (Wilkins andBoard., 1989 and Sikkemaet al., 1995).

This study's findings are consistent with recent research findings such as (Babarabieet al. (2015) and (2016). Those who discovered essential oils with powerful antibacterial activities, like rosemary and peppermint, reduce the number of micros organisms in the solution, optimize the vitality and consistency of flower color and help avoid yellowing and pigment loss in the petals of Alstroemeria cut flowers.

\section{CONCLUSION}

Finally it could be recommended to use Nigella Eo at $200 \mathrm{mg} / \mathrm{l}$ as pulsing for $24 \mathrm{hr}$.then holding in tap water to complete their shelf life period in the case of cut Solidago canadensis cut spike at the normal commercial harvest stage (where only $10 \%$ of florets are opened). This treatment caused increment of the spike vase life (15.78 and 16.85 days) by $140 \%$ more than control plants $(6.98$ and 7 days), increase in final water uptake, chlorophyll $\mathrm{a}$ and $\mathrm{b}$ and decrease of number of bacterial colonies in vase solution. Also, Nigella EO surpassed on rosemary and Lemon Eos for extended Solidago vase life.

\section{REFERENCES}

Abbaszadeh B, SharifiAshourabadi E, Lebaschi MH, Hajibagher MN, Moghadami F (2008). The effect of drought stress on proline, soluble sugars, chlorophyll and relative water contents of balm (Melissa officinalis L.). Iran J Pharm Res.;2008.23:504-513.

Alimoradi M, Poor MJ, Golparvar A (2013). Improving the keeping quality and vase life of cut Astroemeria flowers by post-harvestnano silver treatment. International J. of Agric. and Crop Sci., 6(11):632-635.

Babarabie M, Zarei H, Varasteh F (2015). The Effect of rosemary essential oils and thymol on vase life and some physiological characteristics of Alstroemeria Cut Flowers. International Journal of Agriculture and Biosciences, 4(3): 122-126.

Babarabie M, Zarei H,Varasteh F (2016). Potential of increasing the vase life and improvement of some physiological characteristics of Alstroemeria Cut Flowers by using non-harmful compounds environmentally. Journal of Chemical Health Risks, 6(1): 1-8.

Balestra GM, Agostini R, Bellincontro A, Mencarelli F, Varvaro L (2005). bacterial populations related to gerbera (Gerbera jamesonii L.) stem break. Phytopathol. Mediterr. 44:291-299.

Basiri Y, Zarei H, Mashayekhy K, Pahlavany MH (2011). Effect of rosemary extract on vase life and some qualitative characteristics of cut carnation flowers (Dianthus caryophyllus cv. "White librity"). Stored Products and Postharvest Research, 14: 261 265.

Bayat H, Geimadil R, Saadabad AA ( 2013). Treatment with essential oils extends the vase life of cut flowers of lisianthus (Eustoma grandiflorum). J Med Plants By-Prod, 2:163-169.

Bazaz AM, Tehranifar A (2011). Effect of ethanol, methanol and essential oils as novel agents to improve vase-life of Alstroemeriaflowers. J. Biol. Environ. Sci. 5 (14),41-46. 
Borges A, Ferreira C, Saavedra MJ, Simons M (2013). Antibacterialactivity and mode of action of ferulic and gallic acidsagainst pathogenic bacteria," Microbial Drug Resistance, Vol. 19,No. 4, pp. 256265, 2013.

Brahmankar SE, Dhadukand BK, Singh A (2005). Effect of harvesting stages and chemical preservatives on postharvest life of golden rod (Solidago canadensis Linn.) panicles. Journal of Ornamental Horticulture (New Series), 8(1): 23-26.

Burt S (2004). essential oils their antibacterial properties and potential applications in foods. International Journal of Food Microbiology, 94:223253.

Damunupola JW, Qian T, Muusers R, Joyce DC, Irving DE, Van Meeteren U (2010). Effect of scarvone on vase life parameters of selected cut flower and foliage species. Postharvest Biology and Chem., 31 (3): 426-428.

El-Hanafy HS (2007). Alternative additives to vase solution that can prolong vase life of carnation(Dianthus caryophyllus)flowers. J. Product Dev. 12 (1), 263-276.

Fariman ZK, Tehranifar A (2011). Effect of essential oil, ethanol and methanol to extend the vase life of carnation (Dianthus caryophyllus L.) flowers. J. Biol. Environ. Sci., 5(14):91-94.

Flower Council of Holland (1999). http://www.flowercouncil.co.uk,

Hashemabadi D, Vand SH, Zarchini M, Hajian G, Ghaderi A, Zarchini S (2012). Improvement postharvest longevity flower diameter and solution uptake of chrysanthemum cv. ,white flowers by artemisia oil. Annals of Biological Research, 12:5504-5506.

He S, Joyce DC, Irving DE, Faraghar JD (2006). Stem end blockage in cut Grevillea 'crimson Yul$10^{\text {ee }}$ inflorescences. Postharvest Biology and Technology, 41:78-84.

Hegazi MA, El-Kot G (2009). Influences of some essential oil on vase life of Gladiolus hybrida, L. spikes. In. J.Agro. Vet .Med .Sci. Vol., 3:19-24.

Hoogerwerf A, Van Doorn WG (1992). Numbers of bacteria in aqueous solutions used for postharvest handling of cut flowers. Postharvest BiolTechnol; 1:295-304.

Hossein Dareini, Vahidabdos, Elhamdanaee (2014). Effect of some essential oils on postharvest quality and vase life of gerbera cut flowers (Gerbera jamesonii cv. "Sorbet"). European Journal of Experimental Biology,4(3):276-280.

Irfan Gani, Dar QAH, Mudasir R, Waheed A, Bhat ZA (2018). Effect of essential oils and silver based biocides on the vase life of cut carnation (Dianthus caryophyllus cv. dark-dona). The Pharma Innovation Journal; 7(7): 763-766
Kazemi M, Zamani S, Aran M (2011). Effect of some treatment chemicals on keeping quality and vase life of cut flowers. AM.J. Plant Physiol., 6:99105.

Khimani RA, Thube N, Jadav RG (2005). Effect of stem length and panicle weight on postharvest quality in golden rod (Solidago canadensis Linn.). Journal of Ornamental Horticulture (New Series), 8(4): 287-289.

Melville JKM (1982). A biosystematic study of the Solidagocanadensis (Compositae) complex. The Ontario populations. Can J. Bot.; 60(6):976-997.

Miller GL (1959). Use of dinitrosalicylic acid reagent for determination of reducing sugar. Analytical Chemistry, Vol. 31, no. 3, p.426-428.

Mohammad Hojjati, Hassan Barzegar (2017). Chemical Composition and Biological Activities of Lemon (Citrus limon) Leaf Essential Oil. Vol 4, No. 4, pages: $15-24$.

Moran R (1982). Formula for determination of chlorophyll pigment extracted with N,N diethyl formamide. Plant Physiology, 69: 1376-1381.

Nickavar B, Mojab F, Javidnia K, Amoli MA (2003). Chemical composition of the fixed and volatile oils of Nigella sativa from Iran. Z Natutforsch C; 58(9-10): 629-631.

Okigbo RN (2005). Biological control of postharvest fungal rot of yam (Dioscorea spp.) withBacillus subtilis. Mycopathologia ,159: 307314.

Shanan NT (2012). Applications of essential oils to prolong the vase life of rose (Rosa hybrida L. cv "Grand") cut flowers. J. of Hort. Sci. \& Ornamental Plants, 4(1):66-74.

Sikkema J, Bont AM, Poolman B ( 1995). Microbiological Reviews;59:201-222.

Snedecor GW, Cochran W (1989). Statistical Methods, Eighth Edition, Iowa State subtillis. Mycopathological, 159: 307-314.

Solgi M, Kafi MT, Taghavi S, Naderi R (2009). Essential oils and silver nanoparticles (SNP) as novel agents to extend vase-life of gerbera(Gerbera jamesoniicv.'Dune') flowers. Postharvest Biol. Technol. 53, 155-158.

Steinegger E, Hancel R (1998). phytopharmazie. Springer Verlagr, 35: 354-374.Sue Clarke BSc (Hons) PhD, 2008 in Essential Chemistry for Aromatherapy (Second Edition).

Teissedre PL, Waterhouse AL (2000). Inhibition of oxidation of human low-density lipoproteins by phenolic substances in different essential oils varieties. J. Agric. Food Chem. 48 (9), 3801-3805.

Tembhurne SV, Feroz S, Sakarkar DM (2014). A review on therapeutic potential of Nigella sativa (kalonji) seeds. J. Med Plants Res.; 8:166167. 
Van Meetern U, Iperen WV, Nijsse J, Keijzer K (2001). Processes and xylem anatomical properties involved in rehydration dynamics of cut flowers. Acta Hort., 543:207-211.

Welburn AR (1994). The Spectral Determination of Chlorophylls a and b, as well as Carotenoids, Using Various Solvents with Spectrophotometers of Different Resolution. Journal of Plant Physiology, 144, 307-313.
Wilkins KM, Board RG (1989). Natural antimicrobial system. In: Gould GW (ed) Mechanism of Action of Food Preservation Procedures. Elsevier, New York, pp 285-362.

Zeltzer S, Meir S, Mayak S (2001). Modified atmosphere packaging (MAP) for long-term shipment of cut flowers. Acta Horticulture, 553, 2: 631-634.

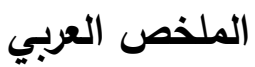

تأثير الزيوت العطرية على حياة إناء الزهور المقطوفة لنبات السوليداجو.

$$
\text { أماني اسماعيل حسن ادم }
$$

فرع بحوث نباتات الزينة بأنطونياس الإنكندرية- قسم بحوث الزينة وتنسيق الحدائق معهد بحوث البساتين مركز البحوث الزراعية

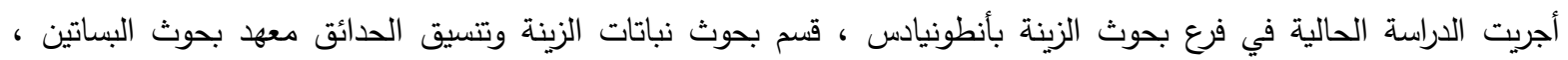

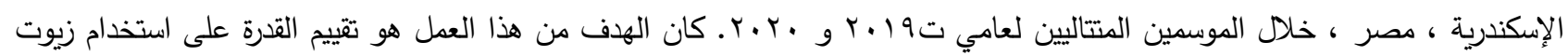

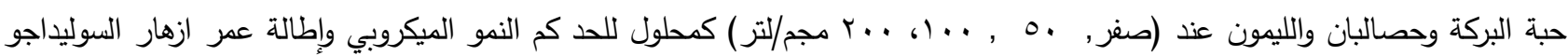

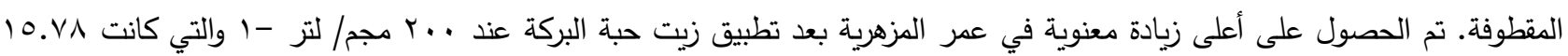

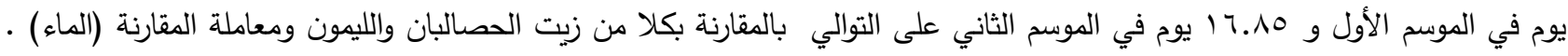

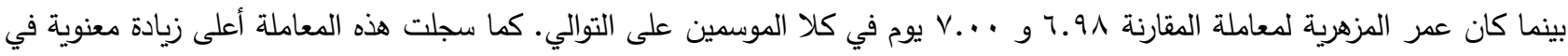

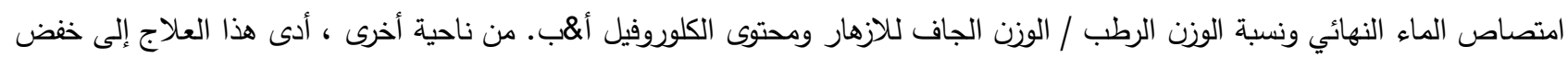

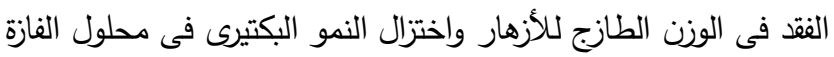

